\title{
PENINGKATAN TATA KELOLA TEKNOLOGI INFORMASI PADA LAYANAN INFRASTRUKTUR JARINGAN MENGGUNAKAN FRAMEWORK COBIT 4.1 DI SINERGI FOUNDATION
}

\author{
Andri Suryadi \\ Prodi Pend Teknologi Informasi STKIP Garut \\ suryadi.andri@yahoo.com
}

\begin{abstract}
Abstrak --- Infrastruktur jaringan sangat mempengaruhi keberlangsungan operasional di Sinergi Foundation oleh karena itu layanan infrastruktur jaringan sangat penting untuk diperhatikan. Idealnya layanan infrastruktur jaringan di Sinergi Foundation dapat memenuhi kebutuhan setiap aktivitas yang ada, namun masih jauh dari harapan sehingga banyak masalah muncul akibat belum sesuainya layanan infrastruktur jaringan tersebut. Sesuai dengan adanya masalah tersebut maka harus ada tata kelola untuk dapat mengukur dan meningkatkan layanan infrastruktur jaringan di Sinergi Foundation. Oleh karena itu penelitian ini akan mengukur dan meningkatkan layanan infrastrktur jaringan di Sinergi Foundation menggunakan Framework Cobit 4.1 dan dan maturity level sebagai alat ukurnya. Hasil yang diharapkan dari penelitian yang telah dilakukan ini adalah adanya rekomendasi untuk dapat meningkatkan layanan infrastruktur jaringan yang telah berjalan. Dengan adanya peningkatan tersebut maka diharapkan masalah - masalah yang terjadi dapat teratasi dan layanan infrastruktur jaringan dapat berjalan sesuai dengan yang diharapkan.

Kata Kunci : Tata kelola, Infrastruktur jaringan, Cobit 4.1, Maturity level
\end{abstract}

\section{PENDAHULUAN}

Teknologi informasi saat ini menjadi salah satu hal yang banyak diadopsi oleh hampir seluruh organisasi baik organisasi yang menghasilkan laba ataupun nirlaba. Teknologi informasi dipercaya dapat meningkatkan tingkat efisiensi dan efektifitas pada sebuah organisasi untuk mencapai tujuannya. Tak terkecuali dengan Sinergi Foundation merupakan sebuah organisasi nirlaba yang bergerak dalam hal pengelolaan Ziswaf (Zakat, infak dan wakaf) yang telah mengadopsi teknologi informasi untuk mencapai tujuannya. Pemamfaatan teknologi informasi di Sinergi Foundation tidak terlepas pada layanan infrastruktur jaringan. Infrastruktur jaringan sangat mempengaruhi keberlangsungan operasional di Sinergi Foundation oleh karena itu layanan infrastruktur jaringan sangat penting untuk diperhatikan.

Layanan infrastruktur jaringan di Sinergi Foundation adalah pada pengadaan, pemeliharaan dan keamanan jaringan. Idealnya layanan infrastruktur jaringan di Sinergi Foundation dapat memenuhi kebutuhan setiap aktivitas yang ada, namun pada kenyatannya layanan infrastruktur jaringan tersebut masih jauh dari harapan sehingga banyak masalah muncul akibat belum sesuainya layanan infrastruktur jaringan tersebut. Sebagai contoh masalah yang terjadi pada pengadaan adalah belum adanya stok barang infrastruktur jaringan sehingga menyebabkan lambatnya pengadaan yang terjadi. Tidak adanya jadwal pemeliharaan menyebabkan kurang terawatnya infrastruktur jaringan yang ada sehingga infrastruktur tersebut menjadi mudah rusak. Dalam hal keamanan jaringan lambatnya pemulihan dari serangan yang disengaja ataupun yang tidak disengaja menjadi masalah yang sering terjadi.

Sesuai dengan adanya masalah tersebut maka harus ada tata kelola untuk dapat mengukur dan meningkatkan layanan infrastruktur jaringan di Sinergi Foundation. Oleh karena itu penelitian ini akan mengukur dan meningkatkan layanan infrastrktur jaringan di Sinergi Foundation menggunakan Framework Cobit 4.1 sebagai alat untuk mendapatkan proses - proses control dari IT goals dan maturity level sebagai alat ukur untuk mendapatkan sejauh mana tingkat layanan infrastruktur jaringan yang sudah berjalan di Sinergi Foundation.

Hasil yang diharapkan dari penelitian yang telah dilakukan ini adalah adanya rekomendasi untuk dapat meningkatkan layanan infrastruktur jaringan yang telah berjalan. Dengan adanya peningkatan tersebut maka diharapkan masalah - masalah yang terjadi dapat teratasi dan layanan infrastruktur jaringan dapat berjalan sesuai dengan yang diharapkan.

\section{LANDASAN TEORI}

Tata kelola teknologi informasi menurut (Khadra H.A., Zuriekat M., and Alramhi N., 2009) adalah tentang bagaimana cara organisasi menyakini bahwa strategi telah diterapkan, diawasi dan diterima hasilnya. Sedangkan menurut Wibowo, et.al. (2007), tata kelola TI (IT Governance) adalah wewenang dan struktur pembuatan keputusan dari pimpinan dan manajer organisasi untuk mengoptimasi dan mengkontrol penggunaan sumber daya teknologi informasi dimulai dari perencanaan, implementasi dan monitoring atau evaluasi untuk mencapai tujuan organisasi dengan menggunakan mekanisme tertentu. Sedangkan Weill (2004) mendefinisikan tata kelola TI sebagai kerangka kerja yang spesifik untuk hak pengambilan keputusan 
dan akuntabilitas untuk mendorong perilaku yang diinginkan dalam penggunaan TI.

Menurut Peterson (2003), tata kelola teknologi informasi lebih luas cakupannya dari pada manajemen teknologi informasi (IT Management). Manajemen teknologi informasi fokus pada penyediaan layanan dan produk teknologi informasi yang efektif untuk internal organisasi dan pengelolaan operasi teknologi informasi saat ini. Sedangkan, tata kelola teknolgi informasi fokus pada menampilkan dan mentransformasikan teknologi informasi untuk memenuhi kebutuhan bisnis (internal focus) saat ini dan masa depan serta untuk memenuhi kebutuhan customer (eksternal focus).

Tata kelola Teknologi Informasi merupakan salah satu aspek penting dari tata kelola perusahaan secara keseluruhan. Pengelolaan teknologi informasi yang baik akan menjamin efisiensi dan pencapaian kualitas layanan yang baik bagi tujuan bisnis perusahaan. Penerapan tata kelola ini $\mathrm{h}^{-\cdots \cdot 1}$ encanakan dengan baik agar dapat diimplementasika ai dengan kondisi dan kemampuan perusahaan. IT Gov e memiliki lima fokus area dalam proses pengelolaantata kelola teknologi informasi sesuai pada gambar 2.1.

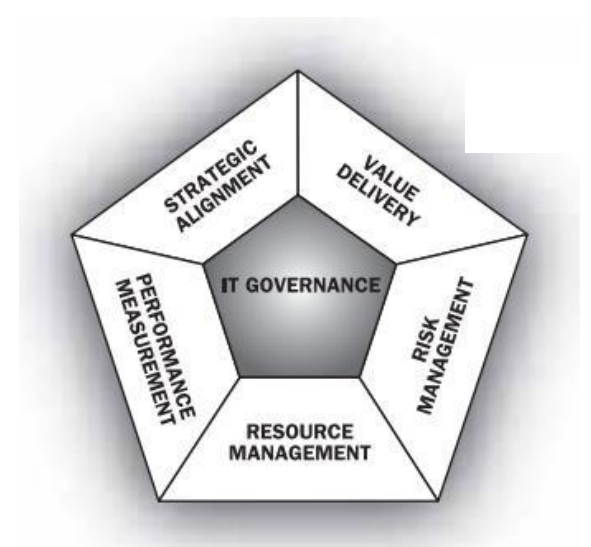

Gambar 2.1 Fokus area IT Governance

Fokus area dari tata kelola teknologi informasi menurut (IT Governance Institute 2007) adalah sebagai berikut: 1. Penyelarasan Strategis (Strategic Alignment)

Memfokuskan kepastian terhadap keterkaitan antara strategi bisnis dan TI serta penyelarasan antara operasional TI dengan bisnis.

\section{Penyampaian Nilai (Value Delivery)}

Mencakup hal-hal yang terkait dengan penyampaian nilai yang memastikan bahwa TI memenuhi manfaat yang dijanjikan dengan memfokuskan pada pengoptimalan biaya dan pembuktian nilai hakiki akan keberadaan TI.

3. Pengelolaan Sumber Daya (Resource Management)

Berkaitan dengan pengoptimalan investasi yang dilakukan dan pengelolaan secara tepat dari sumber daya TI yang kritis mencakup : aplikasi, informasi, infrastruktur dan Sumber Daya Manusia (SDM). Isu kunci area ini berhubungan dengan pengoptimalan pengetahuan dan infrastruktur.

4. Pengelolaan Resiko (Risk Management)
Membutuhkan kepekaan akan resiko oleh manajemen senior, pemahaman yang jelas akan perhatian perusahaan terhadap keberadaan resiko, pemahaman kebutuhan akan kepatutan, transparansi akan resiko yang signifikan terhadap proses bisnis perusahaan dan tanggung jawab pengelolaan resiko ke dalam organisasi itu sendiri.

5. Pengukuran Kinerja (Performance Measurement)

Penelusuran dan pengawasan implementasi dari strategi, pemenuhan proyek yang berjalan, penggunaan sumber daya, kinerja proses dan penyampaian layanan dengan menggunakan kerangka kerja seperti Balanced Scorecard yang menerjemahkan strategi ke dalam tindakan untuk mencapai tujuan terukur dibandingkan dengan akuntansi konvensional.

Selain itu ada lima pilar tata kelola teknologi informasi menurut Weill \& Ross (2004). Weill \& Ross mengusulkan lima pilar utama dari tata kelola teknologi informasi yang ditunjukan pada gambar tabel berikut :

Tabel 2.1 Prinsip tata kelola teknologi informasi

\begin{tabular}{|c|c|c|}
\hline \multicolumn{2}{|c|}{ IT Principles } \\
\hline \multirow{4}{*}{ IT Architecture } & IT Infrastrukture & $\begin{array}{c}\text { IT Invesment } \\
\text { and prioritization }\end{array}$ \\
\cline { 2 - 2 } & $\begin{array}{c}\text { Bussiness } \\
\text { Aplications }\end{array}$ & \\
& \\
\hline
\end{tabular}

Kelima pilar tersebut dapat dijelaskan sebagai berikut :

1. IT Principles

IT principles. Keputusan teknologi informasi ini adalah kumpulan dari pernyataan-pernyataan level eksekutif tinggi tentang bagaimana teknologi informasi dapat digunakan organisasi. Sekali pernyataan diartikulasikan, prinsip TI menjadi bagian dari managemen organisasi, yang terus didiskusikan dan dilaksanakan demi perbaikan organisasi, baik di sektor pemasaran, keuangan, pabrik dan lain-lain.

2. IT architecture

IT architecture decisions. Dengan mengklarifikasikan teknologi sebagai pendukung bisnis organisasi yang telah dikembangkan melalui IT principlies baik secara eksplisit maupun implisit, selanjutnya memerlukan proses standardisasi dan integrasi di dalam suatu organisasi.Arsitektur TI adalah pengorganisasian logika dari data, aplikasi dan infrastruktur yang dikemas dalam suatu kebijakan, hubungan dan pemilihan teknologi untuk mendapatkan integrasi dan standardisasi teknis dan bisnis yang diharapkan

3. IT Infrastructure

IT infrastructure. Prasarana dan sarana teknologi informasi yang menyangkut jaringan, komputer, perangkat 
keras dan lunak lainnya adalah suatu kumpulan komponen yang diharapkan bisa mempercepat proses perhitungan, pengiriman dalam berbagai media informasi (data, informasi, gambar, video, teks) dalam waktu yang singkat dan proses penyimpanan yang efektif.

4. IT Business Application Needs

business applications needs. Dalam pengembagan teknologi informasi keperluan bisnis yang spesifik sehingga kehadiran teknologi informasi memberikan suatu nilai baru bagi organisasi. Dua hal penting dalam identifikasi keperluan bisnis yang terkait dengan teknologi informasi yaitu kreativitas dan disiplin.

\section{IT Investment}

IT investment and prioritization. Investasi teknologi informasi sering menjadi bahan yang sulit dimengerti oleh top manajemen dari suatu organisasi, hal ini dikarenakan nilai baru yang ditimbulkan tidak langsung terasa oleh organisasi. Hal ini tidak kalah penting karena menentukan bagaimana nantinya perkembangan penggunaan teknologi informasi dalam perusahaan untuk periode selanjutnya. Semua pilar saling berkaitan dan saling mendukung.

Salah satu sumber daya teknologi informasi ini adalah infrastruktur TI. Menurut Weill (2004), dalam pelaksanaan tata kelola TI ada lima bidang keputusan yang harus diperhatikan, salah satunya keputusan mengenai infrastruktur TI (IT infrastructure decisions). Pengambilan keputusan yang tepat mengenai infrastruktur TI yang digunakan pada organisasi ini dapat didukung dengan adanya tata kelola infrastruktur TI yang baik (good IT infrastructure governance). Dengan penerapan good IT infrastructure governance ini akan mendorong tercapainya tata kelola TI yang baik (good IT governance) pada organisasi.

\section{A. COBIT 4.1}

COBIT (Control Objectives for Information and Related Technology) adalah sebuah metodologi yang menjadi best practice dalam pengelolaan TI di berbagai sektor industri, termasuk industri teknologi informasi. COBIT dapat membantu pihak manajemen dan pengguna untuk menjembatani gap antara resiko bisnis, kebutuhan kontrol dan permasalahan teknis. Selain itu COBIT merupakan suatu metodologi yang terdiri dari standar dan pengendalian yang dibuat untuk membantu organisasi dalam implementasi, review, administrasi, dan pemantauan lingkungan teknologi informasi. Tujuan utama COBIT adalah memberikan kebijaksanaan yang jelas dan latihan yang bagus bagi IT Governance bagi organisasi di seluruh dunia untuk membantu manajemen senior untuk memahami dan mengatur risiko-risiko yang berhubungan dengan TI. COBIT melakukannya dengan menyediakan kerangka kerja IT Governance dan petunjuk kontrol obyektif yang rinci bagi manajemen, pemilik proses bisnis, pemakai dan auditor.

Menurut IT Governance Institute (2007) kerangka kerja COBIT, terdiri dari tujuan pengendalian tingkat tinggi dan struktur klasifikasi keseluruhan. Terdapat tiga tingkat (level) usaha pengaturan TI yang menyangkut manajemen sumberdaya TI. Mulai dari bawah, yaitu kegiatan dan tugas (activities and tasks) yang diperlukan untuk mencapai hasil yang dapat diukur.
Dalam aktivitas terdapat konsep siklus hidup yang di dalamnya terdapat kebutuhan pengendalian khusus. Kemudian satu lapis di atasnya terdapat proses yang merupakan gabungan dari kegiatan dan tugas (activities and tasks) dengan keuntungan atau perubahan (pengendalian) alami. Pada tingkat yang lebih tinggi, proses biasanya dikelompokkan bersama kedalam domain. Pengelompokan ini sering disebut sebagai tanggung jawab domain dalam struktur organisasi dan yang sejalan dengan siklus manajemen atau siklus hidup yang dapat diterapkan pada proses TI dapat dilihat pada gambar berikut :

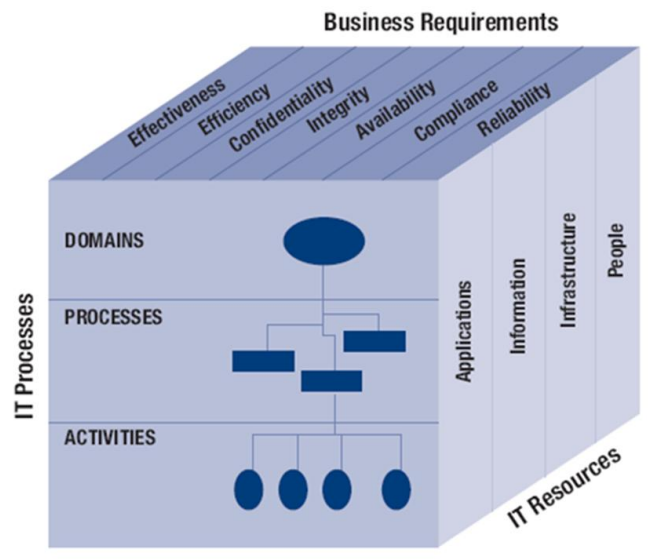

Gambar 2.2. Konsep framework COBIT

Secara keseluruhan konsep framework COBIT terdiri dari : Kebutuhan bisnis, sumber daya teknologi informasi dan proses teknologi informasi.

\section{B. Maturity Level}

Maturity level adalah suatu metode untuk mengukur level pengembangan manajemen proses. Seberapa besar keberhasilan pengembangan atau kapabilitas manajemen tergantung pada tercapainya tujuan COBIT yang sesuai dengan tujuan organisasi. level kematangan (maturity level) digunakan sebagai alat untuk melakukan benchmarking dan selfassessment oleh manajemen teknologi informasi secara lebih efisien. Model kematangan untuk pengelolaan dan kontrol pada proses teknologi informasi didasarkan pada metoda evaluasi perusahaan atau organisasi, sehingga dapat mengevaluasi sendiri, mulai dari level 0 (non-existent) hingga level 5 (optimised). Terdapat enam tingkatan model kematangan yang dapat dilihat pada tabel berikut :

Tabel 2.2. Tabel maturity model

\begin{tabular}{|c|l|}
\hline Level & \multicolumn{2}{|c|}{ Tingkat Kematangan } \\
\hline 0 & Dimana pengelolaan layanan infrastruktur \\
(Non & teknologi informasi masih dalam tahap awal. \\
Existent) & $\begin{array}{l}\text { Proses manajemen tidak ada sama sekali dan } \\
\text { pengimplementasiannya tidak berdasarkan pada }\end{array}$ \\
& suatu metode yang tepat. Perusahaan belum \\
& mengetahui tentang pengelolaan layanan \\
& teknologi informasi dan tidak tersedia \\
& komunikasi mengenai hal tersebut. \\
\hline
\end{tabular}




\begin{tabular}{|c|c|}
\hline Level & Tingkat Kematangan \\
\hline $\begin{array}{c}1 \\
\text { (initial) }\end{array}$ & 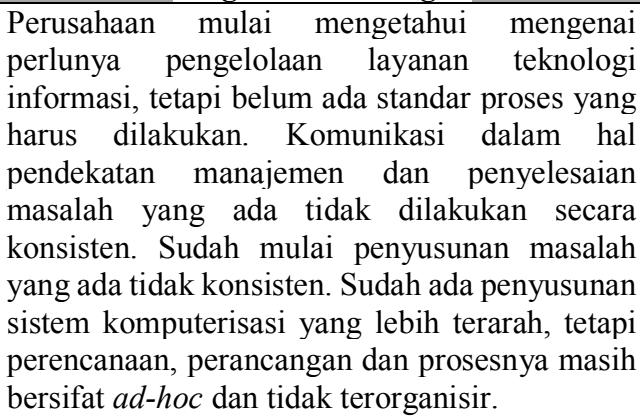 \\
\hline $\begin{array}{c}2 \\
\text { (Repeata } \\
\text { ble but } \\
\text { Intituitiv } \\
\text { e) }\end{array}$ & $\begin{array}{l}\text { Perusahaan mulai menyadari adanya kebutuhan } \\
\text { akan pentingnya layanan teknologi informasi. } \\
\text { Adanya indikator pengukuran kinerja dalam } \\
\text { tahap pengembangan, perencanaan dan } \\
\text { implementasi berbasis komputer telah } \\
\text { menemukan pola terarah, berjalan dengan pola } \\
\text { terstandarisasi. Pihak manajemen telah } \\
\text { mengetahui ukuran dasar pengelolaan layanan } \\
\text { teknologi informasi tetapi proses tersebut belum } \\
\text { dapat diaplikasikan secara menyeluruh pada } \\
\text { perusahaan. Tidak tersedianya pelatihan formal } \\
\text { dan komunikasi mengenai standar layanan } \\
\text { teknologi informasi. Tanggung jawab proses } \\
\text { layanan teknologi informasi dikendalikan oleh } \\
\text { individu. }\end{array}$ \\
\hline $\begin{array}{c}3 \\
\text { (Defined) }\end{array}$ & $\begin{array}{l}\text { Perusahaan telah menyadari dan mengetahui } \\
\text { kebutuhan pengelolaan layanan teknologi } \\
\text { informasi. Telah direncanakannya sekumpulan } \\
\text { aturan untuk indikator dasar pengelolaan } \\
\text { teknologi informasi. Seluruh proses telah } \\
\text { didokumentasikan dan telah dikomunikasikan } \\
\text { serta telah dilaksanakan berdasarkan metode } \\
\text { pengembangan komputerisasi yang baik. Akan } \\
\text { tetapi implementasi diserahkan pada setiap } \\
\text { individu, sehingga kemungkinan penyimpanan } \\
\text { yang terjadi terkadang tidak terdeteksi. }\end{array}$ \\
\hline $\begin{array}{c}4 \\
\text { (Manage } \\
\text { d and } \\
\text { Measura } \\
\text { ble) }\end{array}$ & $\begin{array}{l}\text { Perusahaan telah memahami pengelolaan } \\
\text { layanan teknologi informasi diseluruh bagian } \\
\text { dan didukung dengan pelatihan secara formal. } \\
\text { Pembagian tanggung jawab sudah terbagi secara } \\
\text { jelas. Proses dalam layanan teknologi informasi } \\
\text { disesuaikan dengan kebutuhan bisnis dan } \\
\text { strategi perusahaan. Proses komputerisasi telah } \\
\text { dimonitor dan terukur dengan baik. }\end{array}$ \\
\hline $\begin{array}{c}5 \\
(\text { Optimis } \\
\text { ed) }\end{array}$ & $\begin{array}{l}\text { Proses - proses dalam perusahaan telah } \\
\text { disempurnakan ke praktek terbaik dan } \\
\text { berdasarkan pada hasil peningkatan yang terus - } \\
\text { menerus dan perbandingan model maturity } \\
\text { dengan perusahaan lain. Perusahaan } \\
\text { menggunakan layanan teknologi informasi } \\
\text { sebagai suatu cara terintegrasi untuk } \\
\text { mengoptimalkan arus kerja, menyediakan alat } \\
\text { untuk meningkatkan kualitas dan efektifitas dan } \\
\text { menuntun perusahaan untuk beradaptasi } \\
\text { mengenai pengelolaan layanan teknologi }\end{array}$ \\
\hline
\end{tabular}

\begin{tabular}{|l|l|}
\hline Level & \multicolumn{2}{|c|}{ Tingkat Kematangan } \\
\hline & $\begin{array}{l}\text { informasi dengan cepat serta mendukung } \\
\text { kebutuhan secara menyeluruh. }\end{array}$ \\
\hline
\end{tabular}

Gambaran umum maturity level dapat dilihat pada gambar berikut ini :
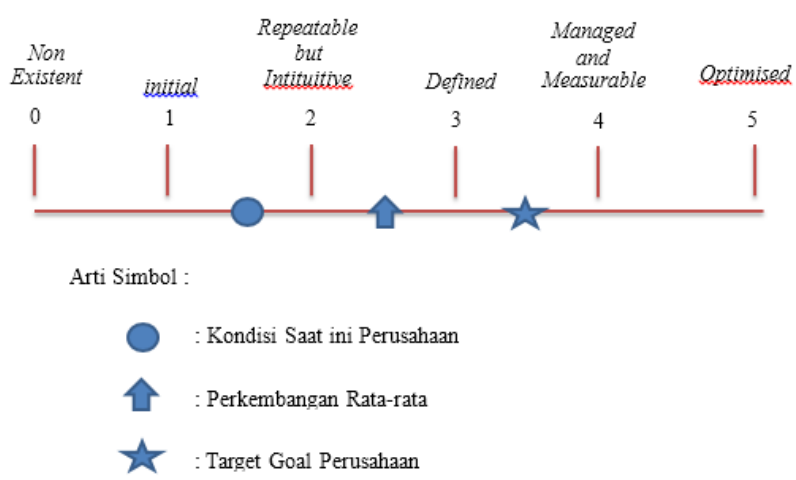

\section{PEMBAHASAN}

\section{A. Telaah Dokumen terkait dengan layanan infrastruktur jaringan}

Tahap pertama dalam analisis dan pembahasan adalah telaah dokumen terkait dengan layanan infrastruktur jaringan. Salah satu dokumen yang ada di Sinergi Foundation adalah adanya tujuan dari divisi teknologi informasi. Tujuan dari divisi teknologi informasi tersebut adalah sebagai berikut :

Tabel 3.1 Tujuan TI Sinergi Foundation

\begin{tabular}{|c|c|c|}
\hline No & Tujuan & Target Sasaran \\
\hline 1 & $\begin{array}{l}\text { Melakukan pengembangan } \\
\text { yang inovatif dibidang } \\
\text { teknologi informasi baik } \\
\text { software ataupun hardware } \\
\text { dan dapat memberikan } \\
\text { solusi terhadap } \\
\text { permasalahan. }\end{array}$ & $\begin{array}{l}\text { Adanya } \\
\text { pengembangan } \\
\text { aplikasi minimal } 2 \\
\text { aplikasi setiap } \\
\text { tahun }\end{array}$ \\
\hline 2 & $\begin{array}{l}\text { Memberikan layanan } \\
\text { pengadaan dan } \\
\text { pemeliharaan infrastruktur } \\
\text { jaringan sesuai kebutuhan. }\end{array}$ & $\begin{array}{ll}\text { - } & \text { Terpenuhinya } \\
\text { kebutuhan setiap } \\
\text { divisi masalah } \\
\text { infrastruktur } \\
\text { jaringan } \\
\text { - Umur infrastruktur } \\
\text { relatif panjang }\end{array}$ \\
\hline 3 & $\begin{array}{l}\text { Menjamin keamanan pada } \\
\text { infrastruktur jaringan dari } \\
\text { hal yang tidak diinginkan } \\
\text { baik disengaja atau tidak } \\
\text { disengaja. }\end{array}$ & $\begin{array}{ll}\text { Tidak adanya } \\
\text { sistem down pada } \\
\text { infrastruktur } \\
\text { jaringan akibat } \\
\text { kesalahan yang } \\
\text { disengaja atau } \\
\text { tidak disengaja }\end{array}$ \\
\hline
\end{tabular}




\begin{tabular}{|l|l|ll|}
\hline No & \multicolumn{2}{|c|}{ Tujuan } & Target Sasaran \\
\hline 4 & $\begin{array}{l}\text { Melakukan pemahaman } \\
\text { teknologi } \begin{array}{l}\text { Persentase } \\
\text { terhadap pihak intern } \\
\text { organisasi. }\end{array}\end{array}$ & $\begin{array}{l}\text { pemahaman } \\
\text { pegawai naik 10\% } \\
\text { setiap tahunnya }\end{array}$ \\
\hline 5 & $\begin{array}{l}\text { Melakukan kontrol dengan } \\
\text { pihak luar yang melakukan } \\
\text { kerjasamaradidang } \\
\text { teknologi informasi }\end{array}$ & $\begin{array}{l}\text { Tidak ada pihak } \\
\text { luar yang loss } \\
\text { control. }\end{array}$ \\
\hline
\end{tabular}

Selain tujuan dari divisi teknologi informasi diatas, terdapat beberapa tugas yang dilakukan oleh divisi teknologi informasi di Sinergi Foundation diantaranya :

1. pegawai dari divisi teknologi informasi untuk pengadaan dan pemeliharaan infrastruktur jaringan

Salah satu penghambat dalam pengadaan dan pemeliharaan adalah keterbatasan pegawai dari divisi teknologi informasi itu sendiri. Saat ini pegawai yang bertugas dalam hal pengadaan dan pemeliharaan berjumlah satu orang sehingga wajar jika dalam hal pengadaan dan pemeliharaan belum sesuai yang diharapkan.

2. Pengadaan dan pemeliharaan infrastruktur jaringan

Kerusakan hardware, software ataupun komponen jaringan disebabkan oleh beberapa faktor berdasarkan kejadian pada saat itu terjadi. Misalnyanya tiba-tiba mouse rusak, monitor tidak berjalan dengan baik ataupun komponen lainnya baru diadakan pengadaan sekaligus pemeliharaan komponen tersebut sekaligus diadakan pemeliharaan seperti membersihkan komponen lain yang terkait didalamnya.

3. Menyediakan layanan permintaan penyediaan dan pemeiharaan infrastruktur jaringan

Pengadaan yang dilakukan merasa lambat karena dilakukan berdasarkan antrian berdasarkan kejadian yang terjadi kepada divisi teknologi informasi sehingga waktu pemulihan menjadi dirasakan sangat lambat. Jumlah pegawai untuk menangani hal ini menjadi salah satu faktor yang sangat berpengaruh.

4. Sebelum dilakukan pengadaan terlebih dahulu pihak dari divisi teknologi informasi melakukan pengecekan terhadap infrastruktur tersebut.

Pegawai yang bertugas untuk melakukan pengadaan tersebut sebelumnya dilakukan analisis atau pengecekan terhadap infrastruktur jaringan yang mengalami masalah. Jika hasil dari analisis harus dilakukan pergantian pada infrastruktur tersebut maka diadakan pengadaan sesuai prosedur yang berlaku.

5. Menyediakan stok barang untuk penyediaan infrasturktur jaringan

Untuk melakukan pengadaan infrastruktur yang mengalami masalah pihak divisi teknologi informasi belum menggunakan stok barang sehingga untuk melakukan pengadaan harus terlebih dahulu melakukan pembelian. Hal ini menjadi salah satu faktor keluhan dari pegawai karena proses pengadaan terasa lambat.
6. Pengadaan software jaringan telah dilakukan dengan menyimpan pada sebuah directory khusus.

Proses pengadaan software telah dilakukan pada sebuah directory khusus. Pegawai diperbolehkan menginstal sendiri sesuai dengan hak akses yang telah diberikan sebelumnya oleh divisi teknologi informasi.

7. Pemeliharaan terhadap infrastruktur jaringan dilakukan berdasarkan waktu luang dari divisi teknologi informasi.

Kondisi saat ini yang terjadi dalam hal pemeliharaan infrastruktur jaringan adalah pemeliharaan berdasarkan waktu luang saja. Hal tersebut dikarenakan jumlah pekerjaan yang belum sebanding dengan jumlah pegawai. Namun meskipun demikian pemeliharaan masih dapat berjalan dengan baik.

8. Standar pemeliharaan infrastruktur dilihat dari kebersihan dan kelayakan yang ada.

Proses pemeliharaan berdasarkan keberesihan dan kelayakan dalam hal pemakaian saja. Prosedur pemeliharaan dilakukan dengan membersihkan infrastruktur yang ada setelah itu dilakukan uji kelayakan berdasarkan fungsi dari pegawai itu sendiri.

9. Laporan kejadian kepada divisi teknologi informasi disampaikan melalui beberapa alternatif komunikasi

Dalam pelaporan untuk dapat mendapatkan pengadaan dan pemeliharaan maka ada beberapa alternatif yang dapat dilakukan oleh pegawai. Diantaranya melalui telepon, yahoo messenger, whatsup, email, sms (short message service).

10. Proses pengadaan dan pemeliharaan dilakukan jika ada laporan dari pegawai

Dalam pengadaaan dan pemeliharaan yang dilakukan oleh divisi teknologi informasi hanya dilakukan jika ada laporan kejadian dari pegawai saja. Namun meskipun demikian pengadaan dan pemeliharaa sudah dapat memenuhi kebutuhan pegawai yang bersangkutan.

11. Form pengadaan infrastruktur dalam bentuk manual.

Form pengadaan infrastruktur jaringan masih dalam bentuk manual, terkadang tidak tercatat oleh divisi teknologi informasi karena keterbatasan pegawai dari divisi teknologi informasi itu sendiri. Divisi teknologi informasi lebih mementingkan terpenuhinya kebutuhan dalam pengadaan itu sendiri dibandingkan pencatatan yang dilakukan.

12. Komputer sudah dilengkapi dengan sistem keamanan login pada masing-masing pegawai.

Dengan adanya sistem client server menjadikan salah satu kelebihan dalam keamanan. Setiap pegawai melakukan login terhadap komputer masing-masing pegawai sehingga keamanan lebih terjaga. Untuk mengakses data dalam jaringan berdasarkan login masingmasing pegawai itu sendiri sehingga keamnan data dapat terjamin kerahasiaannya.

13. Tempat penyimpanan data sudah diatur keamanannya sesuai pengguna yang login pada komputer masingmasing pegawai.

Hal ini masih bersangkutan dengan point no 1. Jika pegawai ingin melakukan manipulasi data pada sebuah 
jaringan maka disesuailam dengan login pada masingmasing komputer. Oleh karena itu pengaturan server sangat menentukan dalam hal kerahasiaan data.

14. Jika pengguna mengakses data yang tidak menjadi haknya maka akan muncul penolakan oleh sistem keamanan.

Bagi pegawai yang ingin mengetahui data yang bukan merupakan haknya maka akan muncul peringatan penolakan pada layar monitor. Penolakan tersebut mengindikasikan bahwa pegawai tersebut bukan hak nya untuk dapat mengakses data.

15. Proses backup data dilakukan oleh pihak divisi teknologi informasi secara rutin minimal satu minggu satu kali.

Proses backup data dirasa belum maksimal hal ini dikarenakan proses tersebut dilakukan pada hari terakhir kerja di setiap minggunya. Proses backup ini menyangkut data penting yang ada diperusahaan yang disimpan di komputer server saja. Sedangkan data yang disimpan pada masing-masing pegawai belum menjadi tanggung jawab divisi teknologi informasi.

16. Koneksi terhadap data pada sebuah jaringan melalui laptop dihubungkan melalui akses poin yang telah disediakan.

Jika pegawai yang memakai laptop maka akses terhadap jaringan melalui layanan akses point. Akses point ini sudah ada pada masing-masing cabang sehingga tidak ada masalah dalam hal jenis perangkat yang digunakan.

17. Akses poin dibedakan antara pegawai dan tamu sehingga jaringan lebih aman digunakan oleh pengguna.

Akses poin yang ada dibedakan antara login pegawai dengan login tamu sehingga data yang ada diserver terjamin keamanannya. Jika yang melakukan akses adalah tamu maka akan dihubungkan terhadap akses poin tamu namun jika yang melakukan akses adalah pegawai maka akan dihubungkan kepada akses poin pegawai.

18. Data yang disimpan pada sebuah jaringan dibatasi hanya $2 \mathrm{~Gb}$ per pegawai sehingga hanya data-data kecil yang dapat disimpan.

Untuk dapat menghemat kapasitas penyimpanan maka setiap pegawai dibatasi penggunaan tempat penyimpanan pada sebuah jaringan. Maksimal penggunaan kapasitas adalah $2 \mathrm{~Gb}$ hal ini untuk mengantisipasi file yang sangat besar disimpan pada sebuah jaringan.

19. Pelayanan instalasi infrastruktur tidak mempengaruhi perubahan keamanan sistem

Secara umum proses instalasi dalam sebuah infrastruktur teknologi informasi tidak mempengaruhi perubahan artinya tidak ada settingan yang diubah jika hanya proses instalasi hanya dilakukan dari sisi client.

20. Install ulang sistem operasi dilakukan dengan menggunakan iso / dvd.

Instalasi yang dilakukan oleh divisi teknologi informasi dalam bentuk file iso atau terkadang masih menggunakan dvd. Namun meskipun demikian kebutuhan dari pegawai masih dapat terpenuhi.
21. Infrastruktur untuk mengakses data dalam setiap jaringan dapat melalui komputer pc dan laptop yang terhubung akses poin.

Infrastruktur dalam mengakses data pada sebuah jaringan dapat melalui komputer pc yang telah disediakan ataupun melalui akses poin. Bagi pegawai yang menggunakan aksen poin dapat dilihat pada papan pengumuman khususinternal perusahaan.

22. Data setiap kejadian dicatat dan dilaporkan setiap bulan sekali

Kejadian yang terjadi dalam sistem jaringan keamanan dicatat pada sebuah buku laporan dan dilaporkan kepihak manajemen. Hal ini dapat berguna untuk pengambilan keputusan yang dilakukan oleh pihak manajemen. Laporan ini sangat penting karena mempengaruhi kepada kebijakan manajemen untuk divisi teknologi informasi.

23. Manajemen pengguna diatur dari sebuah server.

Untuk meningkatkan keamanan data yang disimpan pada sebuah jaringan maka pengguna diatur oleh server yang mana pada saat ini server yang digunakan adalah Windows Server 2003 dan Mikrotik. Manajemen user diatur oleh Windows Server 2003 sedangkan manajemen bandwidth diatur oleh mikrotik.

24. Aturan penggunaan infrastruktur dilakukan secara lisan Aturan penggunaan infrastruktur yang ada di Sinergi Foundation masih dilakukan manual atau masih beserta pengumuman - pengumaman yang dilakukan pada setiap pertemuan.

\section{B. Analisis kondisi layanan infrastruktur jaringan}

Pada saat ini Sinergi Foundation memiliki kurang lebih seratus pegawai yang tersebar diseluruh Jawa barat dan terdapat 12 kantor cabang diseluruh Jawa Barat. Dari 12 kantor cabang tersebut hanya 4 kantor yang telah memiliki infrastruktur jaringan yang memadai seperti sudah terbentuknya topologi jaringan, sudah adanya sistem client - server. Empat kantor Sinergi Foundation tiga diantaranya terdapat di kota Bandung dan satu terdapat di Kabupaten Karawang Jawa Barat. Empat kantor tersebut saling terkoneksi antara satu dengan yang lainnya melalui layanan jaringan internet sehingga layanan infrastruktur jaringan merupakan komponen yang sangat penting yang harus diperhatikan.

Berikut adalah gambaran infrastruktur jaringan di Sinergi Foundation: 


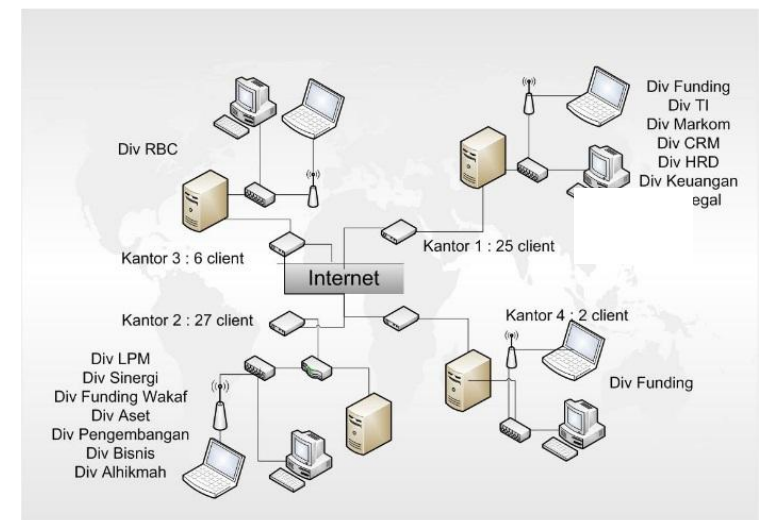

Gambar 3.1. Gambar infrastruktur jaringan Sinergi Foundation

Pada gambar 3.1 menggamba astruktur jaringan di Sinergi Foundation yang terd $\varepsilon_{2}$. + kantor. Infrastruktur tersebut memiliki beberapa spesifikasi yang berbeda diantaranya :

Tabel 3.2 Infrastruktur jaringan Sinergi Foundation

\begin{tabular}{|c|c|c|c|c|c|}
\hline $\begin{array}{l}\mathbf{N} \\
\mathbf{0}\end{array}$ & Jenis & $\begin{array}{c}\text { Kanto } \\
\text { r } 1\end{array}$ & $\begin{array}{c}\text { Kanto } \\
\text { r } 2\end{array}$ & $\begin{array}{c}\text { Kantor } \\
3\end{array}$ & $\begin{array}{c}\text { Kantor } \\
4\end{array}$ \\
\hline 1 & $\begin{array}{l}\text { Personal } \\
\text { Computer } \\
\text { (spesifikas } \\
\text { i } \\
\text { terlampir) }\end{array}$ & $\begin{array}{c}25 \\
\text { client }\end{array}$ & $\begin{array}{c}27 \\
\text { client }\end{array}$ & 6 client & 2 client \\
\hline 2 & $\begin{array}{l}\text { Kecepatan } \\
\text { koneksi } \\
\text { internet }\end{array}$ & $1 \mathrm{Mbps}$ & $2 \mathrm{Mbps}$ & $\begin{array}{c}256 \mathrm{Kbp} \\
\mathrm{s}\end{array}$ & $\begin{array}{c}256 \mathrm{Kbp} \\
\mathrm{s}\end{array}$ \\
\hline 3 & $\begin{array}{l}\text { Swicth } \\
\text { (spesifikas } \\
\text { i } \\
\text { terlampir) }\end{array}$ & 1buah & 1buah & - & - \\
\hline 4 & $\begin{array}{l}\text { Hub } \\
\text { (spesifikas } \\
\mathrm{i} \\
\text { terlampir) }\end{array}$ & 4buah & 5 buah & 1buah & 1buah \\
\hline 5 & $\begin{array}{l}\text { Akses } \\
\text { poin } \\
\text { (spesifikas } \\
\text { i } \\
\text { terlampir) }\end{array}$ & 3 buah & 3buah & 1buah & 1buah \\
\hline
\end{tabular}

\section{Proses pemilihan IT Goal Sinergi Foundation}

Berdasarkan dari telaah dokumen dan analisis kondisi infrastruktur sebelumnya maka didapat dua tujuan divisi teknologi informasi di Sinergi Foundation. Tujuan tersebut merupakan titik awal yang akan dipetakan ke IT goal COBIT 4.1. Tujuan divisi teknologi informasi tersebut adalah sebagai berikut:

1. Memberikan layanan pengadaan dan pemeliharaan infrastruktur jaringan sesuai kebutuhan.
2. Menjamin keamanan pada infrastruktur jaringan dari hal yang disengaja atau ditidak disengaja

D. Proses Pendefinisian IT goals Cobit 4.1

Dari kedua tujuan TI tersebut akan dipetakan kedalam IT Goal Cobit 4.1 berdasarkan kebutuhan Sinergi Foundation terhadap IT Goal Cobit 4.1. Tabel Berikut adalah IT Goal Cobit 4.1.

\begin{tabular}{|c|c|}
\hline No & IT Goals Cobit 4.1 \\
\hline 1 & $\begin{array}{l}\text { Merespon kepada permintaan bisnis yang selaras } \\
\text { dengan strategi bisnis. }\end{array}$ \\
\hline 2 & $\begin{array}{l}\text { Merespon kepada permitaan pemerintahan pada } \\
\text { sebuah line dengan jajaran direksi }\end{array}$ \\
\hline 3 & $\begin{array}{l}\text { Menjamin kepuasan pengguna akhir dengan } \\
\text { penawaran layanan dan tingkat layanan. }\end{array}$ \\
\hline 4 & Mengoptimalkan penggunaan informasi. \\
\hline 5 & Buat kelincahan TI \\
\hline 6 & $\begin{array}{l}\text { Tentukan bagaimana persyaratan fungsional dan } \\
\text { kontrol bisnis dijabarkan dalam solusi otomatis yang } \\
\text { efektif dan efisien. }\end{array}$ \\
\hline 7 & $\begin{array}{l}\text { Memperoleh dan memelihara sistem aplikasi yang } \\
\text { terintegrasi dan terstandarisasi. }\end{array}$ \\
\hline 8 & $\begin{array}{l}\text { Memperoleh dan memelihara infrastruktur } \mathrm{TI} \\
\text { terpadu dan standar. }\end{array}$ \\
\hline 9 & $\begin{array}{l}\text { Memperoleh dan mempertahankan kemampuan IT } \\
\text { yang merespon strategi TI. }\end{array}$ \\
\hline 10 & Menjamin kepuasan saling hubungan pihak ketiga. \\
\hline 11 & Pastikan integrasi aplikasi ke dalam proses bisnis. \\
\hline 12 & $\begin{array}{l}\text { Memastikan transparansi dan pemahaman TI biaya, } \\
\text { manfaat, strategi, kebijakan dan tingkat layanan. }\end{array}$ \\
\hline 13 & $\begin{array}{l}\text { Menjamin penggunaan dan kinerja aplikasi dan } \\
\text { solusi teknologi. }\end{array}$ \\
\hline 14 & Account untuk dan melindungi semua aset TI. \\
\hline 15 & $\begin{array}{l}\text { Mengoptimalkan infrastruktur TI, sumber daya dan } \\
\text { kemampuan. }\end{array}$ \\
\hline 16 & $\begin{array}{l}\text { Mengurangi solusi dan cacat pelayanan dan } \\
\text { pengerjaan ulang. }\end{array}$ \\
\hline 17 & Melindungi pencapaian tujuan TI. \\
\hline 18 & $\begin{array}{l}\text { Menetapkan kejelasan dampak bisnis risiko untuk } \\
\text { tujuan TI dan sumber daya. }\end{array}$ \\
\hline 19 & $\begin{array}{l}\text { Pastikan bahwa informasi penting dan rahasia } \\
\text { dipungut dari orang-orang yang seharusnya tidak } \\
\text { memiliki akses ke sana. }\end{array}$ \\
\hline 20 & $\begin{array}{l}\text { Memastikan bahwa transaksi bisnis otomatis dan } \\
\text { pertukaran informasi dapat dipercaya. }\end{array}$ \\
\hline 21 & $\begin{array}{l}\text { Pastikan bahwa layanan TI dan infrastruktur benar } \\
\text { dapat melawan dan pulih dari kegagalan karena } \\
\text { kesalahan, serangan yang disengaja atau bencana. }\end{array}$ \\
\hline 22 & $\begin{array}{l}\text { Memastikan dampak bisnis minimal dalam hal } \\
\text { terjadi gangguan layanan IT atau perubahan. }\end{array}$ \\
\hline 23 & $\begin{array}{l}\text { Pastikan bahwa layanan TI yang tersedia sesuai } \\
\text { kebutuhan. }\end{array}$ \\
\hline 24 & $\begin{array}{l}\text { Meningkatkan TI efisiensi biaya dan kontribusinya } \\
\text { terhadap profitabilitas bisnis. }\end{array}$ \\
\hline
\end{tabular}




\begin{tabular}{|l|l|}
\hline No & \multicolumn{1}{c|}{ IT Goals Cobit 4.1 } \\
\hline 25 & $\begin{array}{l}\text { Memberikan proyek tepat waktu dan anggaran, } \\
\text { memenuhi standar kualitas. }\end{array}$ \\
\hline 26 & $\begin{array}{l}\text { Menjaga integritas informasi dan infrastruktur } \\
\text { pengolahan. }\end{array}$ \\
\hline 27 & $\begin{array}{l}\text { Pastikan TI kepatuhan terhadap hukum, peraturan } \\
\text { dan kontrak. }\end{array}$ \\
\hline 28 & $\begin{array}{l}\text { Pastikan bahwa TI menunjukkan kualitas pelayanan } \\
\text { hemat biaya, perbaikan terus-menerus dan kesiapan } \\
\text { untuk perubahan masa depan. }\end{array}$ \\
\hline
\end{tabular}

Tujuan divisi TI di Sinergi Foundation akan disesuaikan dengan kebutuhan sehingga IT Goal Cobit 4.1 yang diperoleh merupakan hasil dari kebutuhan Sinergi Foundation. Hasil dari pemetaan dari tujuan divisi teknologi informasi kedalam IT Goal Cobit 4.1 adalah sebagai berikut :

Pada tujuan divisi teknologi informasi pertama yaitu memberikan layanan pengadaan dan pemeliharaan infrastruktur jaringan sesuai kebutuhan di Sinergi Foundation terdapat dua IT Goals Cobit 4.1 yang diperoleh yaitu no 8 (Memperoleh dan memelihara infrastruktur TI terpadu dan standar) dan no 23 (Pastikan bahwa layanan TI yang tersedia sesuai kebutuhan). Gambaran pemetaan tujuan divisi teknologi infomrasi pertama (memberikan layanan pengadaan dan pemeliharaan infrastruktur jaringan sesuai kebutuhan) kedalam IT Goals Cobit 4.1 dapat dilihat pada gambar 4.2 berikut :

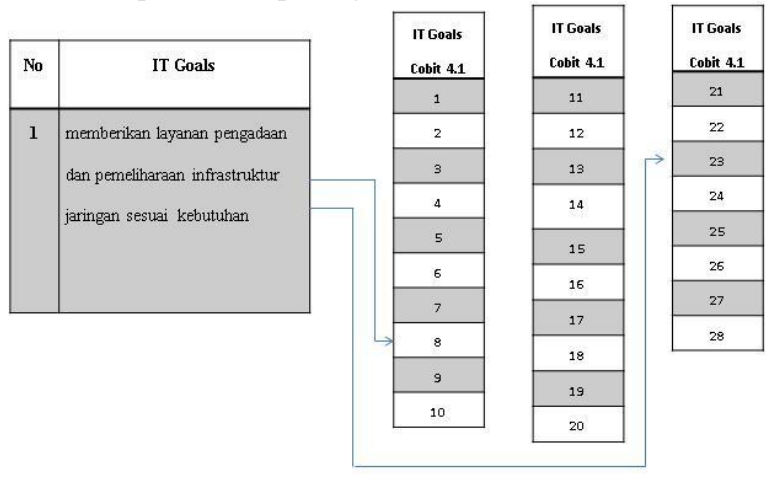

Gambar 3.2 Proses pendefinisian Tujuan pertama (memberikan layanan pengadaan dan pemeliharaan infrastruktur jaringan sesuai kebutuhan) ke dalam Cobit 4.1

Pada tujuan kedua yaitu menjamin keamanan pada infrastruktur jaringan dari hal yang disengaja atau ditidak disengaja diperoleh IT Goals Cobit 4.1 yaitu no 21 (Pastikan bahwa layanan TI dan infrastruktur benar dapat melawan dan pulih dari kegagalan karena kesalahan, serangan yang disengaja atau bencana.). Hasil dari pemetaan tujuan TI ini (yaitu menjamin keamanan pada infrastruktur jaringan dari hal yang disengaja atau ditidak disengaja) ke dalam IT Goals Cobit 4.1 dapat dilihat pada gambar 4.3 berikut :

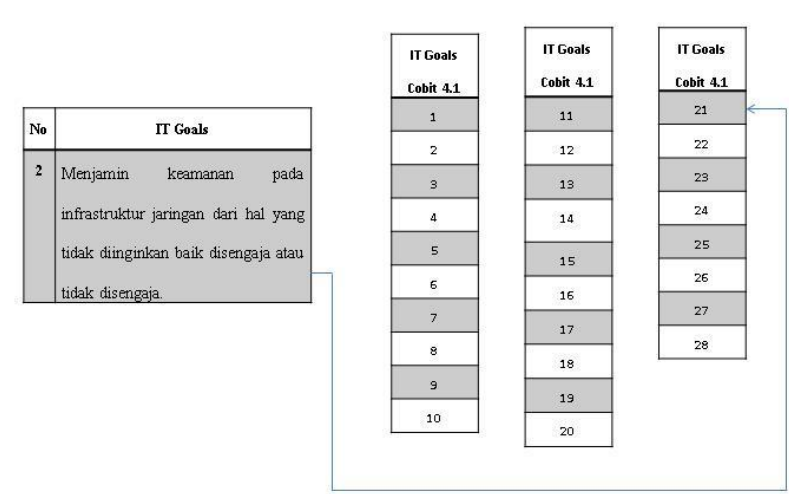

Gambar 3.3 Proses pendefinisian tujuan kedua (Menjamin keamanan pada infrastruktur jaringan dari hal yang tidak diinginkan baik disengaja atau tidak disengaja.) kedalam IT Goal Cobit 4.1

\section{Proses Penentuan IT Proses dari Cobit 4.1}

Sehingga diperoleh IT Goals COBIT 4.1 no 8, 21 dan 23 yaitu Memperoleh dan memelihara infrastruktur TI terpadu dan standar, pastikan bahwa layanan TI yang tersedia sesuai kebutuhan dan pastikan bahwa layanan TI dan infrastruktur benar dapat melawan dan pulih dari kegagalan karena kesalahan, serangan yang disengaja atau bencana. Hasil dari pemetaan tersebut dapat dilihat pada tabel 4.4.

Tabel 3.4 Hasil akhir pendefinisian IT Goal Cobit 4.1

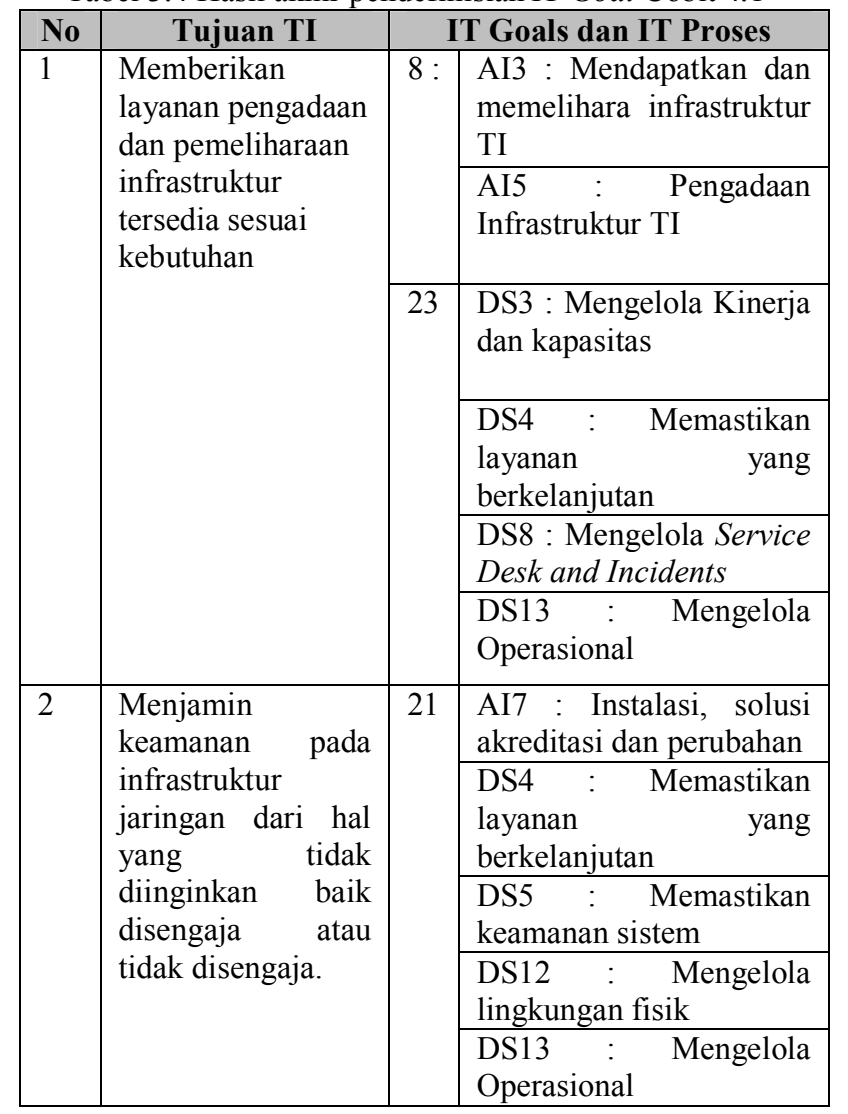


Pada IT Goal no 8 yaitu memperoleh dan memelihara infrastruktur TI terpadu dan standar terdapat dua IT Process diantaranya AI3 (Mendapatkan dan memelihara infrastruktur TI) dan AI5 (Pengadaan Infrastruktur TI). Untuk IT Goal no 23 yaitu Pastikan bahwa layanan TI yang tersedia sesuai kebutuhan terdapat 4 IT Process diantaranya DS3 (Mengelola Kinerja dan kapasitas), DS4 (Memastikan layanan yang berkelanjutan), DS8 (Mengelola Service Desk and Incidents) dan DS13 (Mengelola Operasional). Sedangkan pada IT Goal no 21 yaitu pastikan bahwa layanan TI dan infrastruktur benar dapat melawan dan pulih dari kegagalan karena kesalahan, serangan yang disengaja atau bencana terdapat 5 IT Process diantaranya AI7 (Instalasi, solusi akreditasi dan perubahan), DS4 (Memastikan layanan yang berkelanjutan), DS5 (Memastikan keamanan sistem), DS12 (Mengelola lingkungan fisik) dan DS13 (Mengelola Operasional)

\section{.D. Pengolahan data kuesioner}

Kuesioner penelitian ini dilakukan terhadap 50 orang pegawai Sinergi Foundation namun yang mengisi kuesioner hanya 45 orang saja. Hasil pengukuran tersebut di konversi kedalam maturity level dengan range sebagai berikut :

Tabel 3.5 range maturity level

\begin{tabular}{|c|l|}
\hline range & \multicolumn{1}{|c|}{ Maturity level } \\
\hline $0-0,16$ & $\mathbf{0}$ (Non Existent) \\
\hline $0,17-0,32$ & $\mathbf{1}$ (initial) \\
\hline $0,33-0,48$ & $\mathbf{2}$ (Repeatable but Intituitive) \\
\hline $0,49-0,64$ & $\mathbf{3}$ (Defined) \\
\hline $0,65-0,80$ & $\mathbf{4}$ (Managed and Measurable) \\
\hline $0,80-1$ & $\mathbf{5}$ (Optimised) \\
\hline
\end{tabular}

Hasil dari kuesioner dapat dilihat pada tabel berikut :

E. Hasil pengukuran memberikan layanan pengadaan dan pemeliharaan infrastruktur tersedia sesuai kebutuhan

IT Goals yang telah terdefinisi sebelumnya yaitu memperoleh dan memelihara infrastruktur TI terpadu dan standar dan pastikan bahwa layanan TI yang tersedia sesuai kebutuhan menghasilkan beberapa proses. Hasil pengukuran berdasarkan setiap proses adalah sebagai berikut :

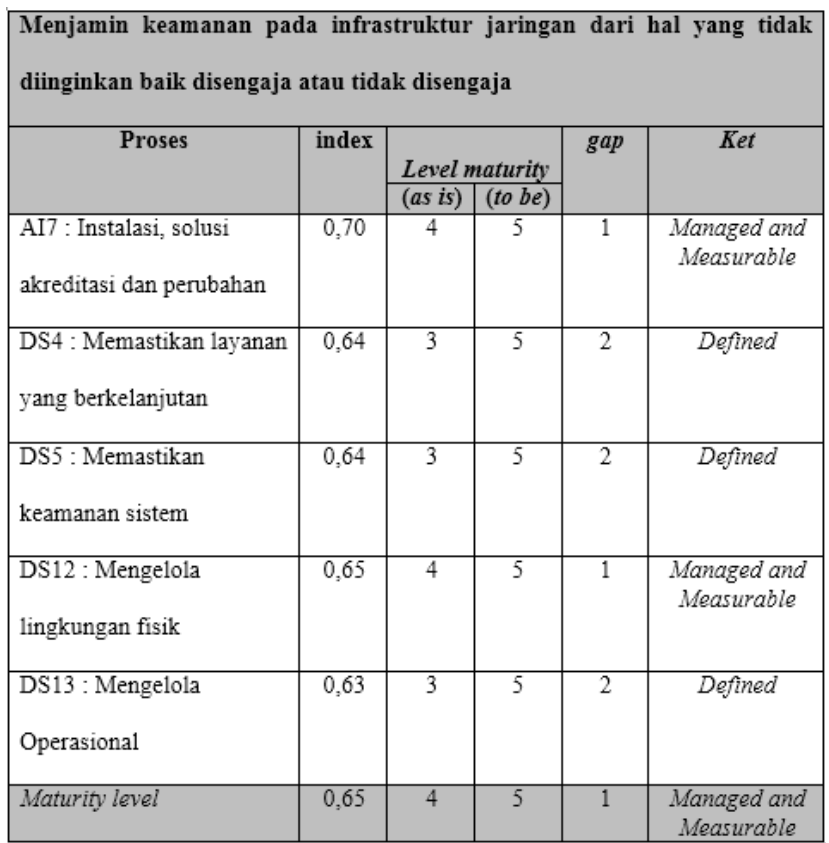

Gambar 3.4 Hasil Analisis IT Goals

Analisis hasil yang didapat dari perhitungan sebelumnya sebagai berikut :

1. AI7 : Instalasi, solusi akreditasi dan perubahan

Hasil yang didapat dari perhitungan pada AI7 adalah

0,70 artinya posisi AI7 pada maturity level berada pada posisi 4

(Managed and Measurable) perusahaan telah memahami dalam instalasi, solusi akreditasi dan perubahan infrastruktur teknologi informasi diseluruh bagian dan didukung dengan pelatihan secara formal. Pembagian tanggung jawab sudah terbagi secara jelas. Proses dalam layanan instalasi, solusi akreditasi dan perubahan teknologi informasi disesuaikan dengan kebutuhan bisnis dan strategi perusahaan. Proses komputerisasi telah dimonitor dan terukur dengan baik.. Sedangkan hasil yang diharapkan adalah pada posisi 5 sehingga menimbulkan gap sebesar 1 .

2. DS4 : Memastikan layanan yang berkelanjutan

Hasil yang didapat dari perhitungan pada DS4 adalah 0,64 artinya posisi DS4 pada maturity level berada pada posisi 3 (Defined) Perusahaan telah menyadari dan mengetahui pentingnya layanan yang berkelanjutan. Layanan ini telah direncanakannya sebelumnya dengan sekumpulan aturan untuk indikator dasar pengelolaan teknologi informasi. Seluruh proses dalam memastikan layanan yang berkelanjutan telah didokumentasikan dan telah dikomunikasikan serta telah dilaksanakan berdasarkan metode pengembangan komputerisasi yang baik. Sedangkan hasil yang diharapkan adalah pada posisi 5 sehingga menimbulkan gap sebesar 2 .

3. DS5 : Memastikan keamanan sistem

Hasil yang didapat dari perhitungan pada DS5 adalah 0,64 artinya posisi DS5 pada maturity level berada pada posisi 3 (Defined) Perusahaan telah menyadari dan mengetahui pentingnya layanan keamanan sistem. Layanan keamanan ini telah direncanakannya sebelumnya dengan sekumpulan aturan 
untuk indikator dasar pengelolaan teknologi informasi. Seluruh proses dalam memastikan layanan keamnana sistem yang telah didokumentasikan dan telah dikomunikasikan serta telah dilaksanakan berdasarkan metode pengembangan komputerisasi yang baik. Sedangkan hasil yang diharapkan adalah pada posisi 5 sehingga menimbulkan gap sebesar 2 .

4. DS12: Mengelola lingkungan fisik

Hasil yang didapat dari perhitungan pada DS12 adalah 0,65 artinya posisi DS12 pada maturity level berada pada posisi 4 (Managed and Measurable) perusahaan telah memahami dalam mengelola lingkungan fisik infrastruktur teknologi informasi diseluruh bagian dan didukung dengan pelatihan secara formal. Pembagian tanggung jawab sudah terbagi secara jelas. Proses dalam layanan dalam mengelola lingkungan fisik infrastruktur teknologi informasi disesuaikan dengan kebutuhan bisnis dan strategi perusahaan. Proses komputerisasi telah dimonitor dan terukur dengan baik.. Sedangkan hasil yang diharapkan adalah pada posisi 5 sehingga menimbulkan gap sebesar 1 .

5. DS13: Mengelola Operasional

Hasil yang didapat dari perhitungan pada DS13 adalah 0,63 artinya posisi DS13 pada maturity level berada pada posisi 3 (Defined) Perusahaan telah menyadari dan mengetahui dalam mengelola operasional dalam keamanan infrastruktur teknologi informasi yang berkelanjutan telah direncanakannya sekumpulan aturan untuk indikator dasar pengelolaan teknologi informasi. Seluruh proses dalam memastikan layanan mengelola operasional telah didokumentasikan dan telah dikomunikasikan serta telah dilaksanakan berdasarkan metode pengembangan komputerisasi yang baik. Akan tetapi implementasi diserahkan pada setiap individu, sehingga kemungkinan penyimpanan yang terjadi terkadang tidak terdeteksi. Sedangkan hasil yang diharapkan adalah pada posisi 5 sehingga menimbulkan gap sebesar 2.

Secara keseluruhan Menjamin keamanan data perusahaan dalam sebuah jaringan berada pada posisi 4 (Managed and Measurable) dengan nilai sebesar 0,65. Perusahaan telah memahami dalam Menjamin keamanan data perusahaan dalam sebuah jaringan diseluruh bagian dan didukung dengan pelatihan secara formal. Pembagian tanggung jawab sudah terbagi secara jelas. Proses Menjamin keamanan data perusahaan dalam sebuah jaringan disesuaikan dengan kebutuhan bisnis dan strategi perusahaan.

Berikut adalah hasil gambar yang dapat dilihat pada Tujuan TI yang kedua.:

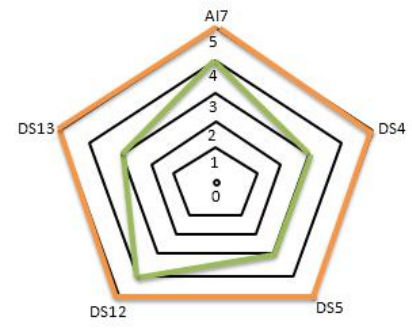

Gambar 3.5 Analisis Gap
Pada gambar diatas garis warna hijau merupakan posisi dimana kondisi proses saat ini (to be). Sedangkan garis warna orange merupakan kondisi level yang diharapkan (as is) Oleh karena itu masih terdapat kesenjangan (gap) yang terjadi sehingga perlu adanya perbaikan untuk meningkatkan level tersebut.

\section{F. Rekomdasi Perbaikan}

Rekomendasi perbaikan untuk mengatasi gap antara kondisi saat ini (as is) dengan kondisi yang diharapkan (to be) yang terjadi di Yayasan Sinergi Foudantion dilakukan secara bertahap pada masing - masing proses berdasarkan nilai dari maturity level yang telah dilakukan sebelumnya.

Rekomendasi perbaikan untuk Tujuan TI sesuai kebutuhan ini sesuai dengan hasil analisis dapat dilihat pada tabel 3.6.

Tabel 3.6 rekomendasi tujuan TI pertama (memberikan layanan pengadaan dan pemeliharaan infrastruktur jaringan sesuai kebutuhan)

\begin{tabular}{|c|c|c|c|c|c|c|}
\hline 5 (Optimised) & & & & & & \\
\hline $\begin{array}{l}4 \text { (Managed } \\
\text { and } \\
\text { Measurable) }\end{array}$ & 余 & $\hat{\uparrow}$ & $\hat{\uparrow}$ & $\hat{\uparrow}$ & $\uparrow$ & $\hat{\uparrow}$ \\
\hline 3 (Defined) & T & & & $\uparrow$ & & $\uparrow$ \\
\hline $\begin{array}{l}2 \text { (Repeatable } \\
\text { but Intituitive) }\end{array}$ & & & & & & \\
\hline 1 (initial) & & & & & & \\
\hline $\begin{array}{l}0 \text { (Non } \\
\text { Existent) }\end{array}$ & & & & & & \\
\hline IT PROSES & AI3 & AI5 & DS3 & DS4 & DS8 & DS13 \\
\hline
\end{tabular}

\section{A. Kesimpukan}

\section{KESIMPULAN DAN SARAN}

Infrastruktur teknologi informasi di Sinergi

Foundation merupakan salah satu penunjang untuk mencapai tujuan bisnis perusahaan. Oleh karena itu perlu adanya pengukuran sejauh mana infrastuktur tersebut dapat memenuhi kebutuhan.

Dari hasil pengukuran yang telah dilakukan menggunakan COBIT 4.1, index kematangan pengadaan dan pemeliharaan infrastruktur sebesar 0,66 atau berada pada level 4 (Managed and Measurable). Berdasarkan maturity level, index kematangan pada pengadaan dan pemeliharaan infrastruktur adalah 1. Sedangkan index kematangan Menjamin keamanan pada infrastruktur jaringan dari hal yang tidak diinginkan baik disengaja atau tidak disengaja adalah 0,65 atau berada pada level 4 (Managed and Measurable). Berdasarkan maturity level, index kematangan pada pengadaan dan pemeliharaan infrastruktur adalah 1.

Dengan adanya rekomendasi perbaikan pada masing masing proses Cobit 4.1 maka diharapkan proses pengadaan dan pemeliharaan sudah ada manajemen yang baik, begitupun dalam hal waktu pemulihan dari bencana yang tidak diinginkan sudah ada rekomendasi peningkatan. 


\section{B. Saran}

Saran penulis terhadap penelitian selanjutnya adalah sebagai berikut :

1. Fokus domain penelitian tidak hanya sebatas pada domain AI dan DS namun diharapkan dengan domain PO dan ME.

2. Penelitian diharapkan tidak sebatas hanya 2 IT Goal saja namun IT goal keseluruhan

3. Diharapkan ada penelitian lanjutan untuk membuktikan kebenaran rekomendasi dari maturity level.

4. Penelitian diharapkan menggunakan framework lain seperti IT Balance scorecard, ITIL dan sebagainya.

\section{DAFTAR PUSTAKA}

Supradono, Bambang. (2011). “Tingkat kematangan tata kelola teknologi informasi (it governance) pada layanan dan dukungan teknologi informasi (kasus : perguruan tinggi swasta di kota semarang)". Semarang : Universitas Muhammadiyah Semarang.

Utomo, Agus Prasetyo. Mariana, Novita . (2011). “Analisis Tata Kelola Teknologi Informasi ( It Governance) pada Bidang Akademik dengan Cobit Frame Work Studi Kasus pada Universitas Stikubank Semarang”. Semarang : Universitas Stikubank Semarang.

Ramadiansyah, Rizki Eka Saputra Dkk. (2011). “Aplikasi tata kelola dan audit sistem informasi menggunakan framework COBIT pada domain PO dan AI". Surabaya : Institut Teknologi Surabaya.

ISACA (2006), COBIT 4.1 Student Book, I T Governance Institute .

Ricoida, Desy Iba . (2008). "Perancangan Tata Kelola TI Untuk Peningkatan Layanan Sistem Informasi Akademik: Studi Kasus STMIK MDP”.

IT Governance Institute, 2007. COBIT 4.1

Framework, Control Objectives, Management Guidelines, Maturity Models, IT Governance Institute.

Kesumawardhani Dwi Rizki.(2012). "Evaluasi IT Governance berdasatkan COBIT 4.1 (Studi kasus PT Timah). Depok : Universitas Indonesia

Yulhendri Dkk.(2008). "Pengembangan Tata Kelola TI untukPengelolaan Sistem Informasi Terintegrasi di Perguruan Tinggi melalui penentuan Kebijakan, Aturan, Pedoman, dan Prosedur “. Bandung : Institut Teknologi Bandung

Hartanto,Indra Dwi.” Analisa kesenjangan tata kelola teknologi informasi untuk proses pengelolaan data menggunakan cobit (studi kasus badan pemeriksa keuangan republik indonesia)". Surabaya : Institut Teknologi Sepuluh Novenber

Kothari,C.R. 2004. Research Methodology:Methods and Techniques. New Delhi: New Age International (P) Ltd., Publishers.
Rozas, Indri Sudanawati.(2012). "Model perhitungan tingkat kedewasaan ti (maturity level) menggunakan framework cobit 4.1" Surabaya : Universitas Narotama Surabaya

Stiawan Deris. (2003). "Mengenal Infrastruktur Jaringan Komputer"

Hendriadi, Ade Andri.(2012). "Pengukuran kinerja sistem informasi akademik dengan menggunakan kerangka kerja cobit 4.1 pada domain plan and organisedi universitas singaperbangsa karawang" Karawang : Universitas Singaperbangsa Karawang

Khadra H.A., Zuriekat M., and Alramhi N., 2009. "An Empirical Examination of Maturity Model as Measurement of Information Technology Governance Implementation." The International Arab Journal of Information Technology, vol.6, no.3, July 2009

IT Governance Institute (2007), "COBIT 4.1 Framework, Control Objectives, Management Guidelines, Maturity Models", IT Governance Institute.

Budiawan, Heri (1996), "Evaluasi Kematangan Pengelolaan Standarisasi Infrastruktur Teknologi InformasiMenggunakanCOBIT(Studi Kasus Badan Pemeriksa KeuanganRI)" Bandung : Institute Teknologi Bandung 